\title{
Regional Airports Influence Economic Development of the Region
}

\author{
Václav Cempírek ${ }^{1}$, and Iveta Dočkalíková ${ }^{2}$ \\ ${ }^{1}$ College of Logistics, Department of Logistics, Palackého 1381/25, CZ 75002 Přerov, Czech \\ Republic; Email: vaclav.cempirek@vslg.cz \\ ${ }^{2}$ College of Logistics, Department of Logistics, Palackého 1381/25, CZ 75002 Přerov, Czech \\ Republic; Email: iveta.dockalikova@vslg.cz
}

\begin{abstract}
The paper deals with the importance of regional airport for economic development of the particular region with the possibility to cover also freight transport. In technical terms it is called the logistics centre or Freight Village. The special emphasis is given to the Pardubice airport and to creation of logistics centre on the Elbe river. The logistics centre would link four types of transport - railway, road, air and inland water transport. Terminal of the combined transport, which lacks in long term in the region, is also a part of the logistics centre.
\end{abstract}

\section{Introduction}

Logistics centres are called multi modal if the access of at least two types of transport is ensured. Multi modal logistics centre means the inter-modal hub of trans-European transport network, where the goods is transhipped between different types of transport. Information and communication technologies help to control and regulate logistics processes and related activities. Such nodes are functional or possible places of business offering wide range of services related to transport. Some nodes are also able to ensure so called City Logistics.

The most suitable places for nodes development are the places where the freight flows are centralized, or the places of significant intersections of transport routes, where the stream of goods changes its direction.

Air transport enables transport of passengers and transport of cargo. It is possible to carry all types of consignments by air transport, e.g. small parcels, standard consignments or over-sized loads. Air transport is fast and safe. Freight air transport in the EU28 indicates only a slight growth (Table 1). It is important, but not crucial, to connect the Pardubice airport to freight air transport [1]. 
Table 1: Freight air transport in the EU28 (in thousands of tones); Source: https://ec.europa.eu/eurostat/web/transport/data/main-tables

\begin{tabular}{|l|c|c|c|c|c|}
\hline & 2008 & 2009 & 2010 & 2011 & 2012 \\
\hline Thousands of tones & 13127 & 13325 & 11495 & 13754 & 13538 \\
\hline & 2013 & 2014 & 2015 & 2016 & 2017 \\
\hline
\end{tabular}

The Pardubice airport is connected with the most known Czech pilot and aircraft designer Ing. Jan Kašpar, who is famous especially thanks to the pioneering long-haul routes. In 1911 the famous "Kašpar flight Pardubice - Velká Chuchle" was realized. Lots of time passed since the beginnings of aviation in Pardubice, but the special spirit is still present.

The joint-stock company EAST BOHEMIAN AIRPORT a.s. (EBA) was established in 1993 with the goal of using the army Pardubice airport for civil operations. The first dispatch of passengers and cargo started in 1994. The shareholders of the EBA company are the town of Pardubice (66\%) and the authority of Pardubice region (34\%).

The modern passenger's terminal was built between $2016-2018$. The dimensions of the building are $160 \times 46 \mathrm{~m}$, built up area is $6120 \mathrm{~m}^{2}$.

The commercial passengers transport was the most significant segment of the airport operation not only in 2017. The number of passengers using the Pardubice airport in 2017 increased by 57 thousand, that is $183 \%$, compared to 2016 .

Table 2: The number of passengers in the Pardubice airport

\begin{tabular}{|l|c|c|c|}
\hline & 2015 & 2016 & 2017 \\
\hline Periodic flights & 33033 & 10251 & 33060 \\
\hline Charter flights & 24915 & 19778 & 54756 \\
\hline General Aviation & 1312 & 1145 & 674 \\
\hline Together & 59260 & 31174 & 88490 \\
\hline
\end{tabular}

The volume of freight transport was by $87 \%$ higher in 2017 compared to 2016 . The airport dispatches only ad hoc cargo flights. Periodic flights are not realized.

Table 3: Freight transport in the Pardubice airport

\begin{tabular}{|l|c|c|c|}
\hline & 2015 & 2016 & 2017 \\
\hline Cargo (in tons) & 159 & 142 & 265 \\
\hline
\end{tabular}

Pardubice is the administrative centre of eastern Bohemia, located $120 \mathrm{~km}$ eastern from Prague. It is the biggest economic centre in the region with high concentration of industry, commercial and public services. Pardubice has its significant place in the economics of the Czech Republic. It is located on the railway corridor No IV and on the European waterway - the Elbe River.

The neighbouring regions of the Pardubice region are Královehradecký, Středočeský, Olomoucký, Jihomoravský and Vysočina region. There is a Czech - Polish border in the north-east. Most of the region is located in the river basin of the Elbe upper stream, the eastern part belongs to the Morava river basin. The economic importance of the region lays in industry, especially in chemical, textile, electro-technical, wood processing, mechanical, energetic industry and in civil engineering [2].

In terms of the above mentioned aspects it is efficient to consider Freight Village in Pardubice. The main goal is to make the Pardubice region and eastern Bohemia more attractive for investors. 


\section{Freight Village (FV)}

Freight Village (germ. Güterverkehrszentrum [GVZ]) is known as the logistics centre, where the goods is reloaded between different types of transport, assembled and prepared for further transport. Different types of transport are concentrated here (e.g. road and rail transport) together with economic subjects (carriers, dispatch, warehouse), subjects offering complementary services (vehicle servicing, consultancy) and economic and business enterprises requesting logistics services. They are all connected in one network. Cooperation and division of labour of particular subjects is supported by the physical closeness.

FV acts as a significant body within transport policy completing by support of combined transport and by shifting long-distance transport from road to railway. Cooperation of the subjects located in FV brings benefits as: better vehicles workload especially in regional road transport (similar as in City Logistics); higher performance is reached in business and services thanks to the synergy between the subjects (formation of clusters). FV should be located close to metropolitan areas with good access to regional and long-distance transport [3].

FV is characterized by the following aspects:

- enter of businesses, logistics services providers and demanding industrial and economic subjects into one business area,

- linking with at least two types of transport, esp. road and rail (terminal of combined transport),

- cooperation activities of FV are initiated and moderated by the control function of FV.

\section{Advantages of FV}

a) Logistics and the factor of economics

- division of labour and outsourcing in business and industry need modern and innovative logistics structures established in FV,

- possibilities of cooperation answering the market needs are offered to middle-sized business subjects,

- the regions are classified as international actors if there is an efficient infrastructure and suprastructure and if the know-how of FV is shared.

b) Trend towards intermodality

- FV as an interface between different types of transport offers optimal conditions for creation of intermodal transport chains,

- business flexibility and safe sustainable assurance of the quality of logistics services rose by the possibilities of alternative types of transport,

- if the FV is located next to the terminal of combined transport, the subjects can use rail and water transport, which will lead to increase of freight transport in these segments in the long-term,

- high affinity of logistics on road transport will be strengthened by efficient cooperation with other types of transport.

c) Head start through synergy

- mix of activities in FV as well as logistics oriented spectra of services offer favourable conditions for new business opportunities,

- management of FV supports the entrance of new business subjects by the comprehensive care and attention and by the support of new product plans, 
- cost savings for businessmen involved are generated thanks to conjunct purchase and pool resources.

d) Linking of logistics structures

- not only reduction in traffic, traffic preclusion and transition, but also adjustment of usage of infrastructure and suprastructure toward future needs of logistics is connected with the term of FV,

- overall benefits of particular FV cannot be judged separately; the more FV, the more interlinked cooperation between them is formed,

- transregional interlink of FV supports efficient business and transport cycles that strengthen competitiveness of economic subjects.

\section{Characteristics of Pardubice and the Pardubice region in terms of FV}

\subsection{Road Transport}

The Pardubice region is connected to the European road network. The four-lane road I/33 is connected to the D 11 highway (Praha - Hradec Králové - Poland). New sections with construction approval should be done in 2024. The proposed foul-line road R 35 (Germany - Liberec - Hradec Králové - Olomouc) in the axis of the original road will go through the whole region form north-west to east [4].

\subsection{Rail transport}

Rail network is relatively dense, but unevenly equipped in terms of technical parameters. It is formed by the lines I. and III. of the speed rail corridor of Czech Railways with the line speed of $160 \mathrm{~km} \cdot \mathrm{h}^{-1}$. The freight transport uses line speed of $120 \mathrm{~km} \cdot \mathrm{h}^{-1}$.

The railway station Pardubice is an important node in the Czech Republic. Rail transport is the basis for combined transport. Location on corridor lanes is very convenient and offers the opportunity for development of domestic and international combined transport.

The line I. of the speed rail corridor leads: Germany - Děčín - Praha - Pardubice - Brno - Austria/Slovakia. The line II: Germany - Cheb - Plzeň - Praha - Pardubice - Ostrava Poland/Slovakia.

\subsection{Inland water transport}

The Elbe River is, in the section from Pardubice, classified as waterway of category E, specifically arterial E20 (Northern Sea - Hamburk - Ústí nad Labem - Mělník - Pardubice) classified according to the European Agreement on Main Inland Waterways of International Importance (AGN). The Elbe waterway is in operation in the section Chvaletice - state border. The necessary condition for realization of the port logistics area in Pardubice is to make the section Chvaletice - Pardubice navigable. Then Pardubice will be directly connected not only to one of the most important maritime port in Hamburk, but also to the whole European waterway network. In order to use the waterway entirely, it is important to make the navigational conditions better in the section Střekov - state border. 


\subsection{Air transport}

The Pardubice international airport is the most significant airport in the region. The airport with military and civil operation enables the flights regime according to visibility (VFR Visual Flight Rules) and according to instruments (IFR - Instrument Flight Rules) including activities needed [5]. The advantages of the airport are the convenient geographic location and the possibility to be used as a backup airport for the Praha Václav Havel airport, Brno airport and Ostrava airport. The next advantage is its location in the administrative centre of the region and in the agglomeration Pardubice - Hradec Králové Chrudim with nearly 250 thousands of inhabitants in range of $35 \mathrm{~km}$.

\section{Data and Methods}

Building the FV Pardubice in the area of important node of the Czech Republic - on the transit railway corridor, close to the airport with international status, at the end of the Elbe waterway with connection to the most important European ports - will create suitable conditions for activation of production and business potential of the whole region of eastern Bohemia [6].

FV Pardubice will have the following advantages:

- Pardubice lays circa in the geographic heart of the Czech Republic,

- it is the important rail node,

- it is connected to the D 11 highway,

- there is the airport with international operation,

- it is assumed that Pardubice will become an important industrial centre,

- Pardubice are considered as the last port on the Elbe waterway.

Realization of the FV project in Pardubce will allow the direct connection of road, rail, water and air transport in one place. This is a premise for formation of logistics node of international importance. The last port on the Elbe waterway connected to the most important European ports will be a part of the node [7]. The conditions for regional development will be better especially in the field of production and business potential.

The benefits of the FV Pardubice not only for the Pardubice region, but also for the neighbouring regions, can be characterized as following:

- strengthening of the importance of the region,

- development of private sector and business support with the impact on international business,

- direct connection to the network of European transport routes,

- strengthening of direct offshore investments in the whole region,

- contribution to the environment by higher share of combined transport,

- reduction in unemployment in the region,

- direct connection of road, rail, water and air transport, which is unique in Europe,

- strengthening of the importance of the Czech Republic as a transit country.

\section{SWOT analysis}

\section{Opportunities:}

- building and development of new FV,

- favourable location of FV,

- support of business development,

- support of the project in regional, national and international documents.

Strengths: 
- using of modern methods,

- settled matrimonial relationship with land,

- proficiency of employees,

- benefit of employment,

- ecological benefit.

Threats:

- problems with completion of the D 11 highway to Poland,

- prolongation of making the Elbe River navigable (to Pardubice),

- possible little interest of investors.

Weaknesses:

- expensiveness of the project,

- transport volumes and overloaded transport network.

\section{Location of the project}

The FV is planned in the area of approx. 30,2 ha. The west border is bounded by Srnojedy village, the northern border is created by the Elbe river, Jesenčanský stream makes the eastern border and the railway line Praha - Pardubice creates the southern border. The defined land belongs to the Prístav Pardubice company [8].

The main parts of the FV are transport infrastructure, warehouses, transhipment stations and area of services [9]. Its layout depends especially on the material flows, product mix of the goods, mouthing of transport infrastructure, technology used, etc.

The suggested areal is divided into the following parts - public port, logistics back area, transport interconnection, connection to utility services.

\section{Discussion}

There are many subjects centralized in the FV, as: terminals of intermodal transport, different subjects working in transport of goods (carriers, hauliers), technical and administrative facilities related to transport (e.g. warehouses, vehicle services, services for intermodal transport units, petrol stations) [10], subjects providing services related to transport (e.g. customs clearance, veterinary inspections, transport under special conditions), or different additional services (e.g. accommodation, catering, parking, etc.).

\section{Conclusion}

Location of the FV in Pardubice was proved by the calculation for finding the peak with the least transport work according to the relation (1).

$$
f\left(D_{k}^{\prime}\right)=\sum \sum 2 * d(u, v) * w(u, v)
$$

Where:

$$
\begin{array}{ll}
\mathrm{d}(\mathrm{u}, \mathrm{v}) & \text { length of the edge }[\mathrm{m}], \\
\mathrm{w}(\mathrm{u}, \mathrm{v}) & \text { weight of the peak [-]. }
\end{array}
$$


It is not clear on which Elbe riverside should be the port and FV located. The first possibility assumes the realization on the left riverside. There are discussions about its location on the right riverside in the area of the Synthesia company since 2016 [11]. The situation is viewed in the Figure $1-\mathrm{A}$ is the original conception, $\mathrm{B}$ is the new possibility for the port and FV location.

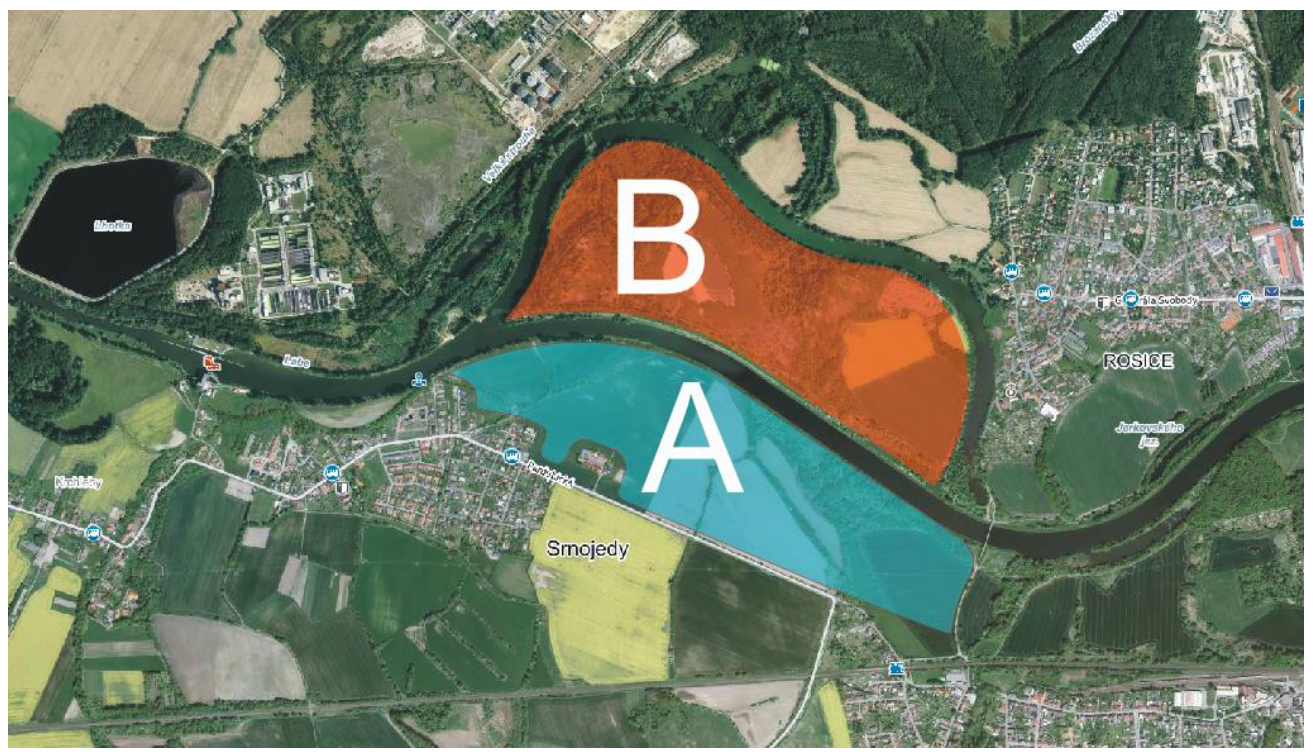

Fig. 1: Possibilities for Srnojedy port location; Source: [12] own adjustment

The suggested solution will interconnect road, rail, inland waterway and air transport in one place and will markedly support development of combined transport and of City Logistics [13].

\section{References}

1. M. Decky, E. Remisova, M. Mecar, L. Bartuska, J. Lizbetin, I. Dreveny. Procedia Earth and Planetary Science: WMESS 2015. 15, p. 11-18. ISSN 1878-5220. (2015)

2. L. Bartuska, V. Biba, R. Kampf. Proceedings of the Third International Conference on Traffic and Transport Engineering (Scientific Research Center Ltd. Belgrade, 2016)

3. J. Jagelcak, J. Vrabel, M. Nieuwesteeg. LOGI Journal. 8, 2 (2017)

4. J. Lizbetin, M. Hlatka, L. Bartuska. Sustainability (Switzerland), 10, 9. (2018)

5. O. Stopka, R. Kampf. Transport, 33, no. 1, p. 280-290. ISSN 1648-4142. (2016)

6. H. Neradilova, G. Fedorko. OPEN ENGINEERING, 6, p. 700-710. (2016)

7. O. Stopka, R. Kampf, J. Kolar, I. Kubasakova, Ch. Savage. Communications. 16, no. 2, p. 14-19. ISSN 1335-4205.(2016)

8. Ch. Li, M. Hlatka. Logi, Vol. 8, No. 1, p. 38-46. ISSN 2336-3037. (2017)

9. J. Hanzl, L. Bartuska, E. Rozhanskaya, P. Prusa. Communications. 18, No. 2, p. 6871. ISSN 1335-4205. (2016)

10. M. Hitka, D. Weberova, L. Lizbetinova, M. Vetrakova. Proceedings of the 30th International Business Information Management Association Conference, IBIMA 
2017 - Vision 2020: Sustainable Economic development, Innovation Management, and Global Growth. p. 436-448, ISBN 978-0-9860419-9-0.

11. Y. Xu, Y. Wang, X. Tao, L. Lizbetinova. Physica A: Statistical Mechanics and its Applications, vol. 487, p. 143-152. ISSN 0378-4371. (2017)

12. Mapy.cz: Maps portal of the Seznam.cz company [online]. ČR: Seznam.cz, 2017 [cit. 2017-05-18]. Available at: https://mapy.cz/

13. G. Fedorko, H. Neradilova, M. Sutak. Transport Means - Proceedings of the International Conference, p. 169-174. (2016) 